\title{
Stable isotope analysis of food source and trophic position of intertidal nematodes and copepods
}

\author{
J. Rzeznik-Orignac ${ }^{1,2, *}$, G. Boucher ${ }^{1}$, D. Fichet ${ }^{3}$, P. Richard ${ }^{3}$ \\ ${ }^{1}$ UMR-CNRS 5178 Biologie des Organismes Marins et Ecosystèmes, Département Milieux et Peuplements Aquatiques, \\ MNHN, CP 53, 61 rue Buffon, 75231 Paris cedex 05, France \\ ${ }^{2}$ Institute of Oceanography, Department of Marine Ecosystem Functioning, Laboratory of Estuarine Ecology, \\ University of Gdansk, Al. Piłsudskiego 46, 81-378 Gdynia, Poland \\ ${ }^{3}$ CRELA UMR 6217 CNRS-IFREMER-Université de La Rochelle, Avenue Michel Crépeau, 17000 La Rochelle cedex 1, France
}

\begin{abstract}
Four dominant nematode species and various copepods from an intertidal mudflat in Marennes-Oléron Bay were analyzed for $\delta^{13} \mathrm{C}$ and $\delta^{15} \mathrm{~N}$ ratios together with their potential food source, the microphytobenthos. It was shown that microphytobenthic $\mathrm{C}$ is passed to nematodes either by grazing or predation on herbivorous meiofauna by other nematodes. Diatoms of different sizes exhibited different ${ }^{13} \mathrm{C}$ content, which can be reflected in herbivorous meiofauna, such as the nematodes Daptonema oxycerca and Metachromadora remanei and the bulk of copepods, indicating they can select different sizes of diatoms. Results confirm the need to analyze meiofauna feeding habits at the species or genera level since the $\delta^{15} \mathrm{~N}$ and $\delta^{13} \mathrm{C}$ signatures differed substantially among meiofaunal species.
\end{abstract}

KEY WORDS: Nematodes $\cdot$ Copepods $\cdot$ Meiofauna $\cdot$ Microphytobenthos $\cdot$ Benthic diatoms $\cdot$ Food web · Mudflat · Marennes-Oléron · Stable isotopes

Resale or republication not permitted without written consent of the publisher

\section{INTRODUCTION}

Numerous studies document meiofauna feeding on epipelic diatoms (Montagna et al. 1995, Riera et al. 1996, Middelburg et al. 2000), but the relative importance of meiofauna in the food web remains uncertain and an object of continuous debate. Some studies indicate that meiofauna have a grazing rate high enough to control microphytobenthic biomass and production (Montagna et al. 1995), whereas other studies suggest that meiofauna use only a small share of $\mathrm{C}$ from primary production (Middelburg et al. 2000, van Oevelen et al. 2006).

Free-living nematodes and harpacticoid copepods often constitute a major part of coastal meiofauna. Harpacticoid copepods are known to consume a wide spectrum of food sources that include microalgae, protazoans, bacteria and organic detritus (De Troch et al. 2006). Interpretation of nematode feeding behaviour is usually based on stoma and pharyngeal morphology, classifying worms into selective and non-selective deposit-feeders, epistrate-feeders or omnivore-carnivores (Wieser 1953). Many species have mouths equipped with teeth, mandibles and/or other sclerotized structures facilitating predacious feeding modes. The absence of empirical evidence about feeding behavior of different taxons hinders proper assessment of their contributions in carbon flows in the benthic food web.

$\mathrm{C}$ and $\mathrm{N}$ stable isotope ratios are commonly used to examine the diets of animals and the structure of food webs in marine ecosystems. Most studies have focused on macrobenthic species or on plankton that can be concentrated via filtration. The analytical method of $\mathrm{C}$ and $\mathrm{N}$ stable isotopes typically requires 1 to $5 \mu \mathrm{g} \mathrm{C}$ per $\mathrm{mg}$ of biomass for reliable detection of isotopic composition (Moens et al. 2005). Since small organisms such as meiofauna have low biomass (about $1 \mu \mathrm{g}$ dry mass), large numbers of individuals must be collected to obtain sufficient material for analysis, impeding iso- 
topic analysis at the species level. When used to elucidate the diet of meiofauna, stable isotope studies often have been restricted to a community level (Couch 1989, Riera et al. 1996, Riera \& Hubas 2003). However, meiofauna are not ecologically homogeneous, and studies at the species level are necessary to improve the understanding of coastal benthic food web complexity. At present, only a limited number of studies at the species level are available: Carman \& Fry (2002) studied the diets of 3 copepods and 2 nematode species, and Moens et al. $(2002,2005)$ studied the diets of a number of nematode species using dual-stable isotope data.

On Brouage Mudflat in Marennes-Oléron Bay, herbivorous nematodes constitute the majority of meiofauna (Rzeznik-Orignac et al. 2003) and can contribute significantly to the regulation of microphytobenthic production (Leguerrier et al. 2003). In the present study the stable isotope compositions $\left(\delta^{13} \mathrm{C}\right.$ and $\left.\delta^{15} \mathrm{~N}\right)$ of 4 dominant nematode species (Rzeznik-Orignac et al. 2003) and of the bulk of copepods and their potential food, microphytobenthos, were examined to better understand the role of meiofauna in the trophic food web.

\section{MATERIALS AND METHODS}

Study site. The present study was conducted in Brouage Mudflat in Marennes-Oléron Bay $\left(46^{\circ} 15^{\prime} \mathrm{N}\right.$, $\left.1^{\circ} 10^{\prime} \mathrm{W}\right)$ along the French Atlantic coast, a shallow intertidal area (avg. depth $4 \mathrm{~m}$ ). The period of emersion is ca. $6 \mathrm{~h}$ per tidal cycle. The sediment is homogeneous in the study area and consists mainly of silt and clay particles with a mean grain size $<10 \mu \mathrm{m}$. These flats are characterized by a high biomass of microphytobenthos (3.8 $\mathrm{g} \mathrm{C} \mathrm{m}^{-2}$ ) (Guarini et al. 1999). The benthic fauna and flora have been previously characterized (Sauriau et al. 1989, Rzeznik-Orignac et al. 2003).

Sample preparation. Samples were collected during emersion at mid-spring tide in July 2003 at the end of the microphytobenthos bloom. Three samples, ca. 21 of mud sediment each, were collected by scraping the upper $2 \mathrm{~cm}$ of sediment from randomly selected patches $(50 \times 50 \mathrm{~cm})$ which were ca. $1 \mathrm{~m}$ apart.

Meiofauna were carefully sieved from the sediment with seawater through a $500 \mu \mathrm{m}$ sieve and simultaneously through a $200 \mu \mathrm{m}$ sieve placed underneath. A large mesh sieve $(500 \mu \mathrm{m})$ was employed to reduce the sediment volume. The fraction retained on the $200 \mu \mathrm{m}$ sieve was used for extraction of animals according to the method described by Couch (1988) and slightly modified by Rzeznik-Orignac et al. (2004). Nematode extraction was performed on 3 independent samples of sediment. Collected animals were starved for $12 \mathrm{~h}$ in $0.7 \mu \mathrm{m}$
GF/F filtered seawater in order to clear gut content. Afterwards, nematodes and copepods were transferred to a counting plate. Nematodes were handpicked with a fine needle, rinsed twice in sterile artificial seawater (ASW) to remove adhering particles and finally transferred to a drop of distilled water in small aluminium cups. Three replicates, each composed of 300 individuals from independent samples for the 4 dominant species (Metachromadora remanei, Sphaerolaimus gracilis, Daptonema oxycerca and Terschellingia longicaudata), were prepared. One hundred randomly selected specimens of the batch of 300 nematodes were measured. Then wet mass of nematodes was calculated using length and width measurements according to Ratsimbazafy et al. (1994). C was conservatively estimated at $10 \%$ of nematode wet weight. Harpacticoid copepods were handpicked directly from the sediment fraction retained on the $200 \mu \mathrm{m}$ sieve and treated the same way as the nematodes.

At the same time and site, benthic diatoms were collected by scraping the upper $5 \mathrm{~mm}$ of sediment and extracted according to the method of Couch (1989). Extracted diatoms were rinsed with filtered seawater and sieved on a column composed of 63 and $25 \mu \mathrm{m}$ sieves. All fractions were retained for analysis: diatoms retained on the $63 \mu \mathrm{m}$ sieve were considered large diatoms $(>63 \mu \mathrm{m})$; those retained on the $25 \mu \mathrm{m}$ sieve were intermediate and those that passed through the $25 \mu \mathrm{m}$ sieve were small. The diatom samples were washed with $1 \mathrm{M} \mathrm{HCl}$ to remove inorganic $\mathrm{C}$ and rinsed with Milli-Q water. Both animals and diatom samples (300 individuals per cup for animals and ca. $10 \mathrm{mg}$ of diatoms per cup) were lyophilized and kept frozen $\left(-40^{\circ} \mathrm{C}\right)$ until analysis.

Isotope analyses. $\mathrm{C}$ and $\mathrm{N}$ isotopic ratios were measured on the same samples and determined using an EA-IRMS Isoprime (Micromass). Results were expressed in the standard \%o unit notation:

$$
\delta \mathrm{X}(\%)=\left(\left[R_{\text {sample }} / R_{\text {standard }}\right]-1\right) \times 10^{3}
$$

where $R$ is either the ${ }^{13} \mathrm{C} /{ }^{12} \mathrm{C}$ or ${ }^{15} \mathrm{~N} /{ }^{14} \mathrm{~N}$ ratio. These values were standardized according to the Vienna Pee Dee Belemnite standard (VPDB) for $\mathrm{C}$ and to air $\mathrm{N}_{2}$ for N. Sample replicate measurements usually differed by less than $0.2 \%$ o for both $\mathrm{C}$ and $\mathrm{N}$. The results provided the mean of the measures and the standard deviations for 3 different samples.

\section{RESULTS}

Obtained biomass (dry weight) was: $330 \mu \mathrm{g}$ for Metachoromadora remanei, $441 \mu \mathrm{g}$ for Daptonema oxycerca, $1860 \mu \mathrm{g}$ for Sphaerolaimus gracilis and $1200 \mu \mathrm{g}$ for copepods. The isotopic signatures of $\delta^{15} \mathrm{~N}$ 


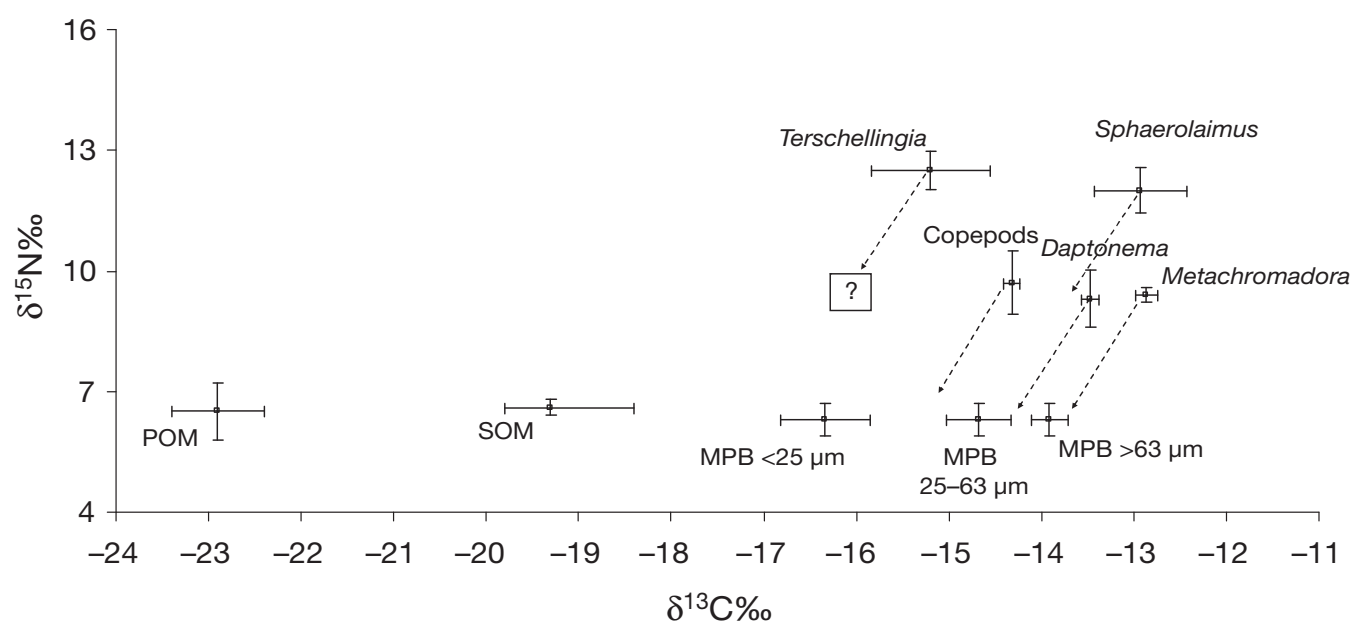

Fig. 1. $\delta^{13} \mathrm{C}$ and $\delta^{15} \mathrm{~N}$ signatures (mean $\pm \mathrm{SD}$ ) for Metachromadora remanei (6 and 3 replicates for $\mathrm{C}$ and $\mathrm{N}$, respectively), Daptonema oxycerca (3 and 4 replicates), Terschellingia longicauda (3 and 2 replicates), Sphaerolaimus gracilis (4 and 4 replicates) and copepods (3 and 2 replicates), sediment particulate organic matter (SOM; 2 and 2 replicates), suspended particulate organic matter (POM; 6 and 2 replicates) are results of Riera et al. (1996) and $\delta^{15} \mathrm{~N}$ for microphytobenthos (MPB; 6 samples) are results of

Riera et al. (1996) and Richard (unpubl. data). Expected enrichment in C and N (trophic shift) is shown by dashed lines

and $\delta^{13} \mathrm{C}$ were plotted on a graph (Fig. 1) for all animals and food sources. The dashed lines in Fig.1 represent the expected trophic enrichment occurring during assimilation of food (trophic shift), generally considered to be close to $1 \%$ for $\mathrm{C}$ and $3 \%$ for $\mathrm{N}$ (McCutchan et al. 2003). Therefore, the $C$ and $N$ isotope signatures of the presumed food have been estimated by removing $1 \%$ for $\mathrm{C}$ and $3 \%$ for $\mathrm{N}$ from the mean isotopic values of consumers.

$\delta^{13} \mathrm{C}$ signatures of the microphytobenthos varied among size fractions: $-16.13 \pm 0.48 \%$ for small, $-14.68 \pm$ 0.35 for intermediate and $-13.91 \pm 0.20 \%$ o for large cells. Unfortunately, a technical problem prevented measurement of $\delta^{15} \mathrm{~N}$ signatures for microphytobenthos. We estimated $\delta^{15} \mathrm{~N}$ for microphytobenthos to be $6.3 \pm 0.4 \%$ (Riera et al. 1996, Richard unpubl. data).

$\delta^{13} \mathrm{C}$ and $\delta^{15} \mathrm{~N}$ values differed among nematode species with a range of -12.9 to $-15.2 \%$ for $\delta^{13} \mathrm{C}$ and 9.3 to $12.5 \%$ for $\delta^{15} \mathrm{~N}$. Three of the 4 studied species (Metachoromadora remanei $[-12.9 \%$, Sphaerolaimus gracilis [-12.9\%] and Daptonema oxycerca [-13.5\%o]) had similar $\delta^{13} \mathrm{C}$ signatures, whereas Terschellingia longicaudata (-15.2\%o) was more depleted. The $\delta^{15} \mathrm{~N}$ signature divided these nematodes into 2 groups: (1) $M$. remanei $(9.4 \%$ ) and D. oxycerca $(9.3 \%$ ) and (2) S. gracilis $(12.0 \%$ ) and T. longicaudata $(12.5 \%$ ) whose signatures were more $\delta^{15} \mathrm{~N}$-enriched. $\delta^{13} \mathrm{C}$ signatures of copepods were depleted compared to nematodes except for T. longicaudata. Their $\delta^{15} \mathrm{~N}$ signatures were close to those of $M$. remanei and D. oxycerca. When taking into account the trophic enrichment, their estimated food had a $\delta^{13} \mathrm{C}$ signature that was close to small diatoms.

\section{DISCUSSION}

In the present study stable isotopes of $\mathrm{C}$ and $\mathrm{N}$ were used to infer food sources of nematodes and copepods. The absence of phanerogams and scarcity of macroalgae in the study area suggests the importance of microphytobenthos as their main food resource. $\delta^{15} \mathrm{~N}$ and $\delta^{13} \mathrm{C}$ for other food sources, such as sediment organic matter (SOM: $-19.3 \pm 0.9 \delta^{13} \mathrm{C}, 6.6 \pm 0.3 \delta^{15} \mathrm{~N}$ ) and suspended particulate organic matter (POM: -22.9 $\pm 0.5 \delta^{13} \mathrm{C}, 6.5 \pm 0.7 \delta^{15} \mathrm{~N}$ ), were based on observations by Riera et al. (1996) collected from the study site at the same time of year (July 2003). As the available data from this mudflat indicated that seasonal and annual variability in SOM C and isotope ratios of microphytobenthos are low (Riera et al. 1996), these results were used in the present study. It was concluded that SOM and POM are much too $\delta^{13} \mathrm{C}$ depleted to constitute the main source of $\mathrm{C}$ for studied nematodes and copepods.

\section{Stable isotope signatures of microphytobenthos}

Moens et al. (2002) suggested that microphytobenthos is usually an assemblage of species with potentially slightly different $\delta^{13} \mathrm{C}$ signatures, and such differences may in turn be reflected in small variations in $\delta^{13} \mathrm{C}$ among herbivorous nematode species that can select their food. The microphytobenthic community in the sampling area includes up to 44 species of different sizes (Haubois et al. 2005). Small species $(<30 \mu \mathrm{m})$ like Navicula phyllepta and Navicula digitoradiata are by far the most abundant species in the community $(91 \%$ 
abundance and $49 \%$ biomass), although large ones like Pleurosigma angulatum may represent a significant part of the biomass (Haubois et al. 2005). $\delta^{13} \mathrm{C}$ results confirm the expected differences of isotopic ratios among the 3 diatom class-sizes, with larger diatoms being more $\delta^{13} \mathrm{C}$-enriched than smaller ones.

It was documented that isotopic fractionation is inversely related to diatom growth rate, and higher growth rates could explain the ${ }^{13} \mathrm{C}$-rich value (Fry \& Wainright 1991). If the observed differences in diatom ${ }^{13} \mathrm{C}$ content could be ascribed to physiological processes in nutrient uptake linked to the large differences in cell size, as small cells usually exhibit higher growth rates than larger ones, small diatoms would be more ${ }^{13} \mathrm{C}$-enriched (Fry \& Wainright 1991). However, the present study shows an inverse trend.

The following explanation can be proposed: selecting the size of diatoms is selecting species, hence their physiology and their behavior. In the surface sediment during low tide, diatoms form dense biofilms where dissolved inorganic carbon (DIC) limitation likely exists. Limitation of DIC can explain benthic diatom ${ }^{13} \mathrm{C}$-enrichment (Forster \& Kromkamp 2006). Due to their limited capacity to withstand the high irradiance levels prevailing at the mud surface, diatoms have a migratory cycling within the top layer of sediment. This migratory cycling, likely to be species-specific, offers diatoms access to different enrichment levels of the DIC pool according to depth. So, different ${ }^{13} \mathrm{C}$ enrichment according to species is likely.

\section{Isotope stable signatures of nematodes and copepods}

A high feeding selectivity has been documented for nematodes grazing on bacteria and microphytobenthos (Moens et al. 1999). The dual isotope signatures used in the present study could discriminate the food sources of meiofauna at species level. The present study reveals the trophic position of some nematode species in the food web of the mudflat of MarennesOléron. Furthermore, the hypothesis that microphytobenthos constitutes an important carbon source for tidal flat meiofauna (Riera et al. 1996, Moens et al. 2002) has been confirmed. The microphytobenthos $C$ is passed to some nematodes either directly by grazing or by predation on herbivorous taxons.

The buccal morphology of Daptonema oxycerca suggests a non-selective deposit-feeding strategy (Wieser 1953). Its food consists mainly of selected particles of different sizes and shapes and often includes diatoms. However, while the $\delta^{15} \mathrm{~N}$ of the source is consistent with the uptake of detritus, the $\delta^{13} \mathrm{C}$ depletion of detritus compared to $\delta^{13} \mathrm{C}$ of nematodes is not consistent with such a feeding habit. The trophic shift as mea- sured in the spring is consistent with $D$. oxycerca feeding exclusively on diatoms. Moens et al. (2005) in the Schelde Estuary (Southwest Netherlands) obtained a dual isotope signature of Daptonema sp. that was depleted compared to epistrate-feeders, suggesting some extra contribution of settled POM. In other locations, such as a mudflat of the northern Gulf of Mexico, ${ }^{13} \mathrm{C}$ and ${ }^{15} \mathrm{~N}$ isotope values indicated that Daptonema sp. exploited mainly Spartina detritus (Carman \& Fry 2002). It suggests Daptonema sp. can be an opportunist species feeding on the most available food resource.

Metachromadora remanei has been considered an omnivore-predator (Wieser 1953), but observations on living nematodes showed that the species feeds like an epistrate-feeder (Moens et al. 2005). Indeed, the $\delta^{15} \mathrm{~N}$ signature is lower than what would be expected from an omnivore and suggests that this species feeds on diatoms longer than $63 \mu \mathrm{m}$. This result is in accordance with those obtained in the Schelde Estuary, which indicates that the Metachromadora sp. population feeds on microphytobenthos (Moens et al. 2005).

Sphaerolaimus gracilis is a large predator-omnivore (body length 1 to $2 \mathrm{~mm}$ ) with a large and heavily cuticularised mouth. Its isotope signatures of $-12.9 \%$ for $\delta^{13} \mathrm{C}$ and $12 \%$ for $\delta^{15} \mathrm{~N}$ are more difficult to interpret since the $\delta^{13} \mathrm{C}$ obtained could be generated by a mixture of food sources. This nematode was observed to consume smaller nematodes. The $\delta^{15} \mathrm{~N}$ signature clearly showed that $S$. gracilis is a second-level consumer feeding on herbivore nematodes and copepods.

Terschellingia longicaudata is considered a bacterivorous nematode (Wieser 1953) with an elongated body and a small mouth cavity. With its small mouth $(3 \mu \mathrm{m})$, $T$. longicaudata cannot feed on protozoans and small metazoans, which makes bacteria a possible food source. The $\delta^{13} \mathrm{C}$ and $\delta^{15} \mathrm{~N}$ of bacteria from Brouage Mudflat were not measured. No measurement of $\delta^{15} \mathrm{~N}$ is available for bacteria in sediment. From a compilation of data on $\delta^{13} \mathrm{C}$ of bacterial biomarkers, bacterial phospholipid fatty acids (PLFA), typical values are in the range of -15 to $-20 \%$ in marsh and unvegetated sediments (Bouillon \& Boschker 2006). The $\delta^{13} \mathrm{C}$ signatures of bacteria and $T$. longicaudata are thus compatible with the assumption of a bacterial food source for T. longicaudata.

The use of microphytobenthos extracellular polymeric substances (EPS) as a carbon substrate for bacteria has previously been suggested (Middelburg et al. 2000). This hypothesis is again consistent with the $\delta^{15} \mathrm{~N}$ signature of predated bacteria, which can be deduced from the signature of T. longicaudata. Assuming bacteria is the only food source of $T$. longicaudata, the $\delta^{13} \mathrm{C}$ signatures suggest that this nematode probably feeds on heterotrophic bacteria using microphytobenthos EPS and detritus. Although T. longicaudata feeds on a 
mix of several sources, dissolved organic matter, bacteria and microphytobenthos EPS cannot be excluded without further investigations.

The stable isotope data for Harpacticoid copepods from the mudflat of Marennes-Oléron showed that these animals feed mainly on microphytobenthos. Their $\delta^{13} \mathrm{C}$ was depleted when compared to the nematodes Metachromadora remanei, Daptonema oxycerca and Sphaerolaimus gracilis, suggesting a larger contribution of the smallest diatoms. Nonetheless, other studies, for example in the Gulf of Mexico (Carman \& Fry 2002), showed that copepods may have different diets: the copepod species Pseudostenhelia sp. feeds mainly on phytoplankton detritus and Coullana sp. feeds on a mixture of benthic microalgue, phytoplankton and Spartina detritus.

Our investigation of meiofauna species-specific nutrition confirms the food habits of species Sphaerolaimus gracilis and Metachromadora remanei, inferred either from direct observation or mouth morphology. It shows also that some species, such as Daptonema oxycerca, can exhibit different diets according to the food source available. This raises questions about the feeding behavior of nematodes: are they highly specialized or opportunistic? We conclude that the stable isotope analysis is a useful technique for determining meiofauna diet and provides insight into the benthic food web structure. The present data, providing information on the diets of meiofauna at a species level, improves the understanding of trophic position as well as the source of $\mathrm{C}$ of those small invertebrates and, therefore, advances knowledge on the processes involved in the fate of local organic matter or resource partitioning among co-occurring species in the coastal benthic food web.

Acknowledgements. The Polonium programme (a FrancoPolish grant), the University of La Rochelle, the University of Gdansk and the Muséum National d'Histoire Naturelle in Paris financially supported this work. We thank G. Guillou from CRELA in l'Houmeau for isotopic analyses. We also thank T. Meziane from MNHN in Paris and R. M. Warwick from Plymouth Marine Laboratory for comments and English corrections.

\section{LITERATURE CITED}

Bouillon S, Boschker TS (2006) Bacterial carbon sources in coastal sediments: a review based on stable isotope data of biomarkers. Biogeosciences 3:175-185

Carman KR, Fry B (2002) Small-sample methods for $\delta^{13} \mathrm{C}$ and $\delta^{15} \mathrm{~N}$ analysis of the diets of marsh meiofaunal species using natural-abundance and tracer-addition isotope techniques. Mar Ecol Prog Ser 240:85?92

Couch CA (1988) A procedure for extracting large numbers of debris-free, living nematodes from muddy marine sediments. Trans Am Microsc Soc 107:96-100
Couch CA (1989) Carbon and nitrogen stable isotopes of meiobenthos and their food resources. Estuar Coast Shelf Sci 28:433-441

> De Troch M, Chepurnov V, Gheerardyn H, Vanreusel A, Olafsson E (2006) Is diatom size selection by Harpacticoid copepods related to grazer body size? J Exp Mar Biol Ecol 332:1-11

Forster RM, Kromkamp JC (2006) Estimating benthic primary production: scaling up from point measurements to the whole estuary. In: Kromkamp JC, de Brouwer JFC, Blanchard GF, Forster R, Créach V (eds) Functioning of microphytobenthos in estuaries. Royal Academy of Arts and Sciences, Amsterdam, p 109-111

> Fry B, Wainright SC (1991) Diatom sources of ${ }^{13} \mathrm{C}$-rich carbon in marine food webs. Mar Ecol Prog Ser 76:149-157

Guarini JM, Gros P, Blanchard GF, Bacher C (1999) La dynamique à court terme de la biomasse du microphytobenthos intertidal. Formalisation mathématique. CR Acad Sci Ser III Sci Vie 322:363-373

Haubois AG, Sylvestre F, Guarini JM, Richard P, Blanchard GF (2005) Spatio-temporal structure of the epipelic diatom assemblage from an intertidal mudflat in MarennesOléron Bay, France. Estuar Coast Shelf Sci 64:385-394

Leguerrier D, Niquil N, Boileau N, Rzeznik J, Sauriau PG, Le Moine O, Bacher C (2003) Numerical analysis of the food web of an intertidal mudflat ecosystem on the Atlantic coast of France. Mar Ecol Prog Ser 246:17-37

McCutchan JH, Lewis WM, Kendall C, McGrath CC (2003) Variation in trophic shift for stable isotope ratios of carbon, nitrogen, and sulphur. Oikos 102:378-390

Middelburg JJ, Barranguet C, Boschker HTS, Herman PMJ, Moens T, Heip CHR (2000) The fate of intertidal microphytobenthos carbon: an in situ ${ }^{13} \mathrm{C}$-labeling study. Limnol Oceanogr 45:1224-1234

Moens T, Verbeeck L, De Maeyer A, Swings J, Vincx M (1999) Selective attraction of marine bacterivorous nematodes to their bacterial food. Mar Ecol Prog Ser 176: $165-178$

> Moens T, Luyten C, Middelburg JJ, Herman PMJ, Vincx M (2002) Tracing organic matter sources of estuarine tidal flat nematodes with stable carbon isotopes. Mar Ecol Prog Ser 234:127-137

> Moens T, Bouillon S, Gallucci F (2005) Dual stable isotope abundances unravel trophic position of estuarine nematodes. J Mar Biol Assoc UK 85:1401-1407

> Montagna PA, Blanchard GF, Dinet A (1995) Effect of production and biomass of intertidal microphytobenthos on meiofaunal grazing rates. J Exp Mar Biol Ecol 185:149-165

> van Oevelen D, Soetaert K Middelburg JJ, Herman PMJ, Moodley L, Hamels I, Moens T, Heip CHR (2006) Carbon flows through a benthic food web: integrating biomass, isotope and tracer data. J Mar Res 64:453-482

Ratsimbazafy R, Boucher G, Dauvin JC (1994) Mesures indirectes de la biomasse des nématodes du méiobenthos subtidal de la Manche. Cah Biol Mar 35:511-523

> Riera P, Hubas C (2003) Trophic ecology of nematodes from various microhabitats of the Roscoff Aber Bay (France): importance of stranded macroalgae evidenced through $\delta^{13} \mathrm{C}$ and $\delta^{15} \mathrm{~N}$. Mar Ecol Prog Ser 260:151-159

- Riera P, Richard P, Grémare A, Blanchard G (1996) Food source of intertidal nematodes in the Bay of MarennesOléron (France), as determined by dual stable isotope analysis. Mar Ecol Prog Ser 142:303-309

> Rzeznik-Orignac J, Fichet D, Boucher G (2003) Spatio-temporal structure of the nematode associations of the Brouage Mudflat (Marennes-Oléron). Estuar Coast Shelf Sci 58: $77-88$ 
Rzeznik-Orignac J, Fichet D, Boucher G (2004) Extracting massive numbers of nematodes from muddy marine deposits: efficiency and selectivity. Nematol 6:605-616

Sauriau PG, Mouret V, Rincé JP (1989) Organisation trophique de la malacofaune benthique non cultivée du

Editorial responsibility: Victor de Jonge,

Hull, UK bassin ostréicole de Marennes-Oléron. Oceanol Acta 12: 193-204

Wieser W (1953) Die Beziehungen zwischen Mundhöhlengestalt, Ernährungsweise und Vorkommen bei freilebenden marinen Nematoden. ArkZool 4:439-484

Submitted: February 10, 2007; Accepted: November 11, 2007 Proofs received from author(s): April 14, 2008 